\title{
The Advancement Value Chain: An Exploratory Model
}

Received (in revised form): September 1, 2004

\section{Edward F. Leonard III}

The author is currently the vice president for college advancement at a small, private, midwestern college. Previously he has served as director of development and director of alumni relations at a southern, public, regional university and as director of alumni programs at a small, private, midwestern college. He has worked in advancement for 15 years and has nine years working in corporate America and association management.

\begin{abstract}
Since the introduction of the value chain concept in 1985, several varying, yet virtually similar, value chains have been developed for the business enterprise. Shifting to higher education, can a value chain be found that links together the various activities of advancement so that an institution's leaders can actually look at the philanthropic implication of various managerial and policy decisions in a rigorous way?
\end{abstract}

\section{Keywords:}

development, alumni relations, public relations, management, president, board of trustees

\section{Introduction}

Since Michael Porter first introduced the concept of the value chain-that "every firm is a collection of activities that are performed to design, produce, market, deliver, and support its product" -other authors and researchers have expanded

\footnotetext{
Author's Contact Address:

Edward F. Leonard III, Ph.D.

Vice President, College Advancement

Wilmington College

Wilmington, Ohio,

USA

Phone: + 19373838511

Email: ed_leonard@wilmington.edu
}

and refined the value chain concept beyond this original definition. In particular, over the last ten years, the concept of the value chain has been extended to those value-creating activities that are performed to improve the financial performance of the business enterprise. The question that is now posed is whether or not a value chain can be extended to higher education and, more specifically, to the higher education advancement enterprise, with advancement being defined as the collection of activities that are performed by the areas of development, alumni relations, and public relations to generate voluntary financial support for the institution. The process employed in this undertaking, after first reviewing several for-profit financial performance value chains, will be to hypothesize and assess an advancement value chain utilizing the multivariate procedure structural equation modeling.

\section{Value chains}

Heskitt et al. ${ }^{2}$ developed a service-industry model (see Figure 1) and concluded that their value chain:

shows the direct links we have measured and documented between 


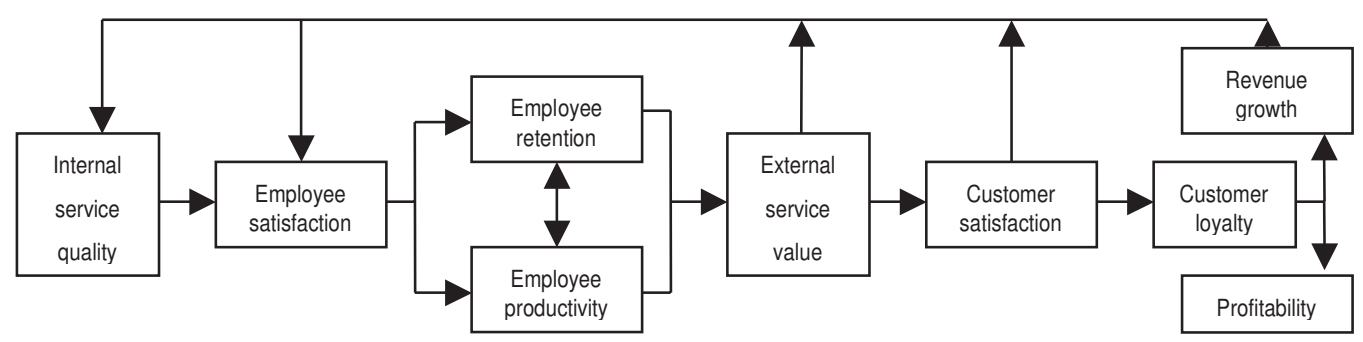

Figure 1: The service profit chain

profit and growth: customer satisfaction and loyalty; the value of services and goods delivered to customers; employee satisfaction, loyalty, and productivity; and what we term "capability" that employees have to deliver results to customers in every outstanding service organization we have observed. While the strength of several of these links in the chain may differ from one organization to the next, the pattern is undeniably significant. ${ }^{3}$

At Sears Roebuck, as management worked to turn the company around, a group of managers, called the Phoenix Group, "in the course of rethinking what Sears was and wanted to become ... developed a business model of the company that tracked success from management behavior through employee attitudes to customer satisfaction and financial performance." 4 Then, sharing the outcomes that emerged from this management-led initiative, Rucci et al. reported on the resulting value chain (Figure 2) and quantitatively demonstrated that employee satisfaction drives customer loyalty, which in turn drives profit. That is, Rucci et al. reported that a five-point increase in employee satisfaction would drive a 1.3 point improvement in customer satisfaction which would, in turn, drive a 0.5 percent improvement in revenue growth.

Maister, wanting to counsel managers on how to create a high-achievement culture, used data from more than 5,500 survey respondents from 139 offices operated by 29 separate firms owned by the same publicly held marketing communications company to develop a

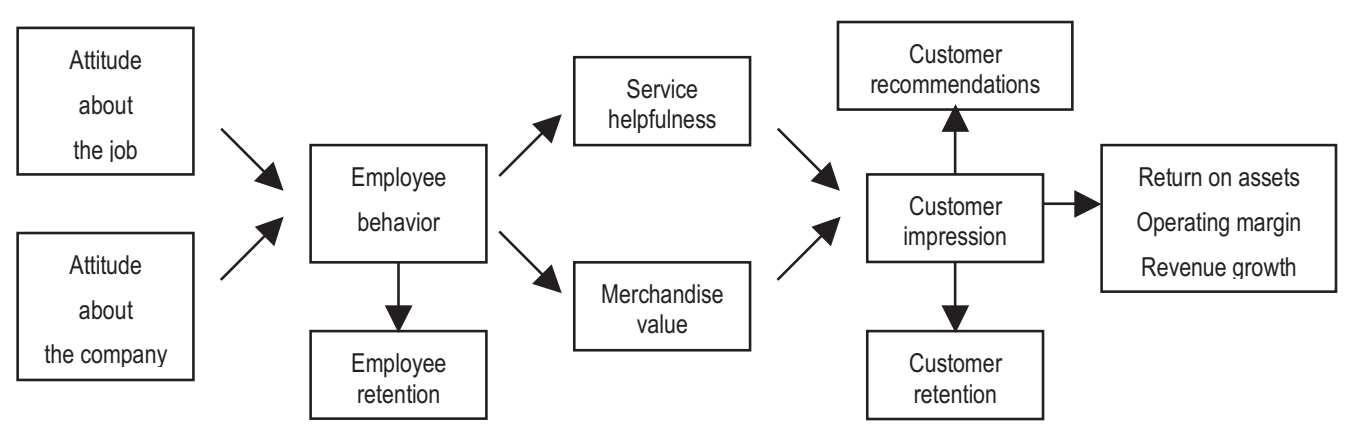

Figure 2: The employee-customer profit chain 


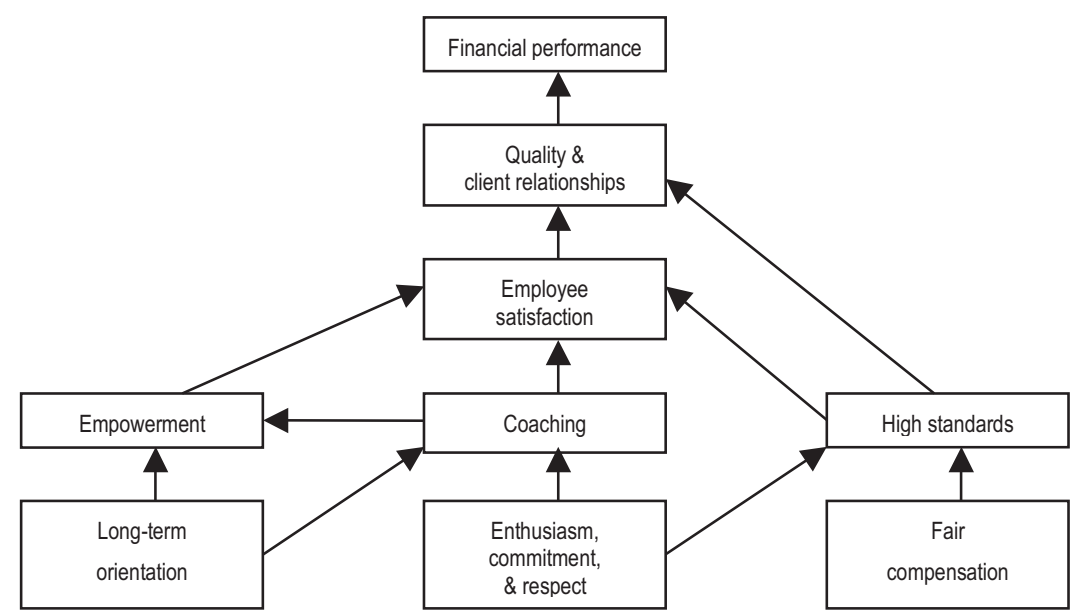

Figure 3: The path to financial performance

firm-specific model (Figure 3) where "for the first time, we can now actually look at the profit implication of various managerial and policy decisions in a rigorous way." 5 Maister employed the multivariate procedure structural equation modeling to construct and confirm his model.

With a similar goal, but employing different analysis procedures, Coffman and Gonzalez-Molina, ${ }^{6}$ working as part of the Gallup Organization and basing their findings on in-depth interviews by Gallup of over 80,000 managers in over 400 companies, developed their own model. They concluded (see Figure 4) that real profit increase drives stock increases, sustainable growth drives real profit increase, loyal customers drive sustainable growth, engaged employees drive customer loyalty, and the right people in the right roles with the right managers drive employee engagement.

A close review of these four independently developed models-or value chains-reveals considerable overlap

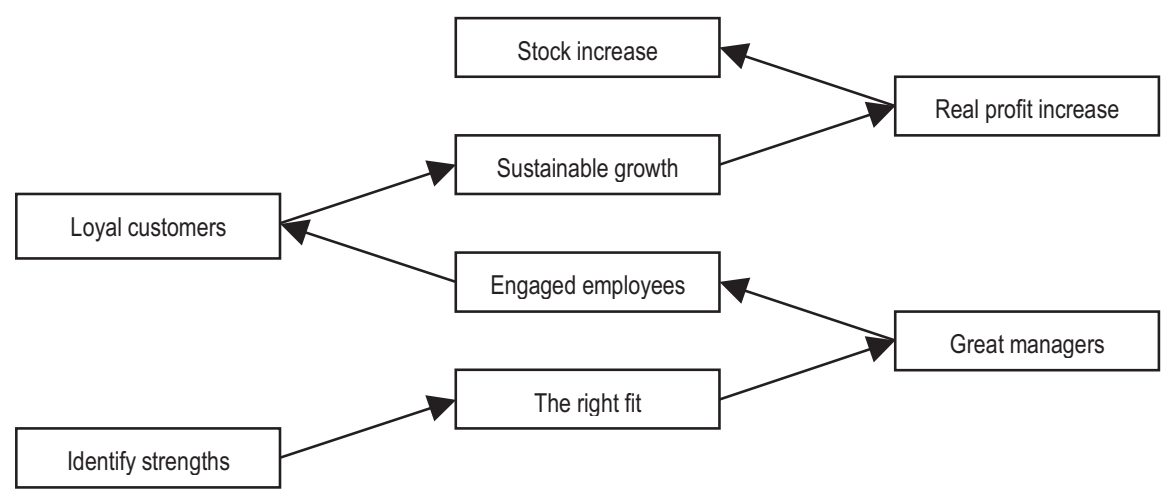

Figure 4: The Gallup path to business performance 
and agreement on the activities-or links-that yield improved financial performance for the business enterprise. There is complete agreement, albeit expressed in slightly different ways, that there is a collection of activities within the business enterprise that forms the links creating an employee-customerprofit value chain.

\section{College/university advancement}

Shifting from the business enterprise to the advancement enterprise of higher education, advancement activities at a small, private college are expected to "provide major streams of income... and serve as their lifeblood for surviving and thriving.", That is, the advancement enterprise provides the institution with an economic value-added margin that is above and beyond tuition, fees, room, and board. Falling under the advancement umbrella, according to the Council for the Advancement and Support of Education's website (www.case.org), are the primary core activities of development, alumni relations, and communications/ marketing (or public relations). In fact, these three were the largest, and most significant, areas falling under the executive management responsibilities of the chief advancement officer, as reported by Willmer in a survey of small, private colleges where "fund raising [development] is under the advancement umbrella at 99 percent of the institutions, alumni at 97 percent, public relations at 82 percent ....,"8

In executing the expectations for advancement, each core activity fulfills a different role as explained by Willmer and others in a book published by the Council for the Advancement and Support of Education (CASE) on advancing small colleges. Public relations has "been charged with the task of defining, improving, and marketing . . . [an] institution's image"; 9 while alumni relations manages "building friendships, raising alumni support, and helping recruit students"; ${ }^{10}$ and development is the "ongoing process committed to the financial and physical growth" $" 11$ of the small private college. Furthermore, "at a minimum, any development operation should include such key functions as: major gifts, planned or deferred gifts, corporate and foundation grants, and annual funds."12

For clarity, according to a glossary of fund-raising terms, major gifts are defined as "gifts of substantial magnitude"; 13 deferred gifts are "gifts to be given at some future date"; ${ }^{14}$ corporate and foundation grants are "generally an allocation from a foundation or corporation;"'15 and annual funds, or annual giving, are "gifts on a yearly basis usually to support in part or totally general operations." "16 Lastly, these development functions secure funds, according to the Council for Aid to Education (CAE), for three possible purposes: current operations, capital, and endowment. ${ }^{17}$

The purpose of this study focuses on whether or not variables can be identified from available public domain information from which will emerge a collection of activities within the advancement enterprise that forms the links creating a public relations-alumni relationsdevelopment value chain for the small private college/university. In other words, stated as the research question, can a value chain be specified, estimated, assessed, and presented, which includes no less than one variable from each core activity of advancement, and that explains what drives the total voluntary financial support for the small private college/ university? 


\section{Structural equation modeling}

To answer that question, a multivariate analysis procedure called structural equation modeling (SEM) was employed.

Structural equation modeling provides the researcher with the ability to accommodate multiple interrelated dependence relationships in a single model. Its closest analogy is multiple regression, which can estimate a single relationship (equation). But SEM can estimate many equations at once, and they can be interrelated, meaning that the dependent variable in one equation can be an independent variable in other equation(s). ${ }^{18}$

SEM is superior to general path analysis because measurement errors can be taken into account in the model, whereas general path analysis cannot solve this problem. ${ }^{19}$ Ultimately, the goal in building an SEM is "to find a model that fits the data well enough to serve as a useful representation of reality and a parsimonious explanation of the data." 20

There are four broad steps involved in SEM construction: (1) model specification, (2) model estimation, (3) model fit, and

(4) model presentation. Model specification begins the construction process with the researcher's a priori hypothesis about those causal paths which are important. Model estimation generates an estimated population covariance matrix from the model. These can be chosen by the researcher from prior information, by computer programs used to build SEMs, or from multiple regression analysis. The goal of model estimation is to produce a population covariance matrix that converges upon the observed population covariance matrix with the residual matrix being minimized. Various methods can be used to generate the population covariance matrix. Choice of method is guided by the attributes of the data including sample size and distribution. Most processes are iterative. Ullman and Hoyle discuss the advantages and limitations of the various estimators. ${ }^{21}$ Maximum likelihood and generalized least squares are useful for normally distributed data when factors and errors are independent. Asymptotically distribution free is useful for nonnormally distributed data, but is shown to work well with sample sizes above 2,500.

Next, the model is assessed for fit. There are three broad categories of fit: absolute, incremental, and parsimonious. Absolute fit measures assess overall goodness-of-fit for both the structured and measurement models collectively, and include $\chi^{2}$, degrees of freedom (df), and the resulting level of statistical significance (p). Incremental and parsimonious fit measures are non- $\chi^{2}$-distributed fitting functions. ${ }^{22}$ The incremental fit measures compare the fit of a null model (i.e., a model that asserts no relationships between variables) to the fit of the estimated model. The result of this comparison is usually a number between 0 and 1 , with 0.90 or greater indicating a good fit. Furthermore, the other non- $\chi^{2}$ distributed fitting function, parsimonious fit measures, assesses overall goodness-offit by representing the degree of model fit per estimated coefficient where the amount of fit per estimated coefficient is maximized. Normed- $\chi^{2}$ (i.e., $\chi^{2} / \mathrm{df}$ ) is a parsimonious fit measure, although there is some disagreement for the "fit" of this measure. Ullman suggests that if the ratio is less than two, the model is a good fit. ${ }^{23}$ On the other hand, Carmines and McIver suggest that the ratio should be in the 2:1 to $3: 1$ range for an acceptable fit, while Kline further suggests that 3 or less is acceptable. $^{24}$ 
More importantly, however, is to use multiple indices when assessing model fitness. ${ }^{25}$ Then, if the estimated matrix does not adequately reproduce the sample matrix, hypotheses are modified and the model retested. To modify the model, new paths are added or original paths are removed.

Lastly, when the model has attained an acceptable fit, individual estimates are assessed. That is, the parameters are compared to a null value using a $z$ distributed statistic. The $\mathrm{z}$ statistic is obtained by dividing the parameter estimate by the standard error of that estimate. The critical ratio of this test must exceed 1.96 for the relationship to be significant. After each relationship within the model is assessed, parameter estimates are standardized for final presentation. With parameter estimates standardized, the paths can be interpreted with reference to other parameters in the model and relative strength of the paths within the model can be compared.

\section{Method}

\section{Participants}

This study used as its participants the 109 institutions comprising the Midwest region of the Comprehensive CollegesBachelor's category in US Newes \& World Report's "Best Colleges" rankings (Table 1). From this group, those institutions that voluntarily reported fund raising and other institutional data to the CAE's annual Voluntary Support of Education survey for fiscal years 1998, 1999, 2000, 2001, and 2002 became the focus group of the analysis. Those institutions and the years data were reported are identified in Table 2. For the five-year analysis period, 246 surveys were submitted by 59 institutions, with 231 being the final group as 15 surveys were disqualified due to missing study-specific data. From the final 231, the top quartile $(\mathrm{N}=58)$ was identified then analyzed based on total voluntary support (Table 3).

The rationale for studying the top quartile-as opposed to the entire groupwas to focus the analysis on "best-ofgroup" causal relationships. The findings, and resulting model, could then be better utilized as a strategic planning tool. Also, the rationale for the 1998 to 2002 time period was because the 1996 revision of the CASE Management Reporting Standards took effect with the 1998 Voluntary Support of Education Survey, and with that came significant changes in reporting standards from the pre-1998 surveys.

The variables used in this study to build an SEM are listed and defined in Table 4. All data were mined using the data-mining feature of CAE's website. The academic reputation data were collected from the respective issue of US Neres d World Report.

\section{Procedure}

Building the model followed the four steps discussed earlier. To specify various hypothesized models, this study, however, did not begin with a priori models.

Instead, this study began with one goal for the final model: to specify at least one variable from each of advancement's three core activities. To aid the model specification process, a correlation matrix was created. From this matrix, several waves of model hypothesizing occurred. The first wave was to hypothesize which variables with strong positive correlations (a negative correlation in an SEM is nonsensical as a causal link) would be a prospective link that might drive total voluntary support. The second wave was to hypothesize which variables with strong positive correlations would be a 
Table 1: Midwest Comprehensive Colleges-Bachelor's (US Newes \& World Report)

Alverno College (Milwaukee, WI)

Augustana College (Sioux Falls, SD)

Baker College of Flint (Flint, MI)

Barat College (Lake Forest, IL)

Bethany College (Lindsborg, KS)

Bethel College (IN)

Bethel College (North Newton, KS)

Black Hills State University (Spearfish, SD)

Bluffton College (Bluffton, $\mathrm{OH}$ )

Briar Cliff University (Sioux City, IA)

Buena Vista University (Storm Lake, IA)

Calumet College of Saint Joseph (Whiting, IN)

Calvin College (Grand Rapids, MI)

Carroll College (Waukesha, WI)

Cedarville University (Cedarville, $\mathrm{OH}$ )

Central Christian College (McPherson, KS)

Central College (Pella, IA)

Central Methodist College (Fayette, MO)

Central State University (Wilberforce, $\mathrm{OH}$ )

Clarke College (Dubuque, IA)

College of Saint Mary (Omaha, NE)

College of the Ozarks (Point Lookout, MO)

Columbia College (Columbia, MO)

Concordia College (Ann Arbor, MI)

Concordia University - St. Paul (St. Paul, MN)

Crown College (St. Bonifacious, MN)

Culver-Stockton College (Canton, MO)

Dakota State University (Madison, SD)

Dakota Wesleyan University (Mitchell, SD)

Dana College (Blair, NE)

Defiance College (Defiance, OH)

Dickinson State University (Dickinson, ND)

Dordt College (Sioux Center, IA)

East-West University (Chicago, IL)

Elmhurst College (Elmhurst, IL)

Eureka College (Eureka, IL)

Evangel College (Springfield, MO)

Franklin College (Franklin, IN)

Grace College (Winona Lake, IN)

Graceland University (Lamoni, IA)

Grand View College (Des Moines, IA)

Greenville College (Greenville, IL)

Hannibal-LaGrange College (Hannibal, MO)

Huntington College (Huntington, IN)

Illinois College (Jacksonville, IL)

Indiana University East (Richmond, IN)

Indiana University Kokomo (Kokomo, IN)

Iowa Wesleyan College (Mt. Pleasant, IA)

Jamestown College (Jamestown, ND)

Judson College (Elgin, IL)

Kansas Wesleyan University (Salina, KS)

Kendall College (Evanston, IL)

Lakeland College (Sheboygan, WI)

Loras College (Dubuque, IA)

Lourdes College (Sylvania, OH)
MacMurray College (Jacksonville, IL)

Manchester College (North Manchester, IN)

Marian College (Indianapolis, IN)

Marietta College (Marietta, $\mathrm{OH}$ )

Martin University (Indianapolis, IN)

Mayville State University (Mayville, ND)

McKendree College (Lebanon, IL)

McPherson College (McPherson, KS)

Midland Lutheran College (Fremont, NE)

Millikin University (Decatur, IL)

Missouri Baptist College (Saint Louis, MO)

Missouri Southern State College (Joplin, MO)

Missouri Valley College (Marshall, MO)

Missouri Western State College (Saint Joseph, MO)

Morningside College (Sioux City, IA)

Mount Mercy College (Cedar Rapids, IA)

Mount Senario College (Ladysmith, WI)

Mount Union College (Alliance, $\mathrm{OH}$ )

Mount Vernon Nazarene College (Mount Vernon, $\mathrm{OH}$ )

Northland College (Ashland, WI)

Northwestern College (Orange City, IA)

Northwestern College (St. Paul, MN)

Notre Dame College of Ohio (South Euclid, OH)

Ohio Dominican University (Columbus, $\mathrm{OH}$ )

Ohio Northern University (Ada, OH)

Ottawa University (Ottawa, KS)

Otterbein College (Westerville, $\mathrm{OH}$ )

Purdue University-North Central (Westville, IN)

Rochester College (Rochester Hills, MI)

Saint Joseph's College (Rennesselear, IN)

Saint Mary's College (Orchard Lake, MI)

Saint Mary's College (Notre Dame, IN)

Saint Mary-of-the-Woods (Saint Mary-of-the-Woods, IN)

Simpson College (Indianola, IA)

Southwest State University (Marshall, MN)

Southwestern College (Winfield, KS)

St. Norbert College (De Pere, WI)

Sterling College (Sterling, KS)

Tabor College (Hillsboro, KS)

Taylor University (Upland, IN)

Tri-State University (Angola, IN)

Trinity Christian College (Palos Heights, IL)

Union College (Lincoln, NE)

University of Minnesota-Crookston (Crookston, MN)

Upper Iowa University (Fayette, IA)

Urbana University (Urbana, $\mathrm{OH}$ )

Valley City State College (Valley City, ND)

Waldorf College (Forest City, IA)

Wartburg College (Waverly, IA)

Wilberforce University (Wilberforce, $\mathrm{OH}$ )

William Penn University (Oskaloosa, IA)

William Tyndale College (Farmington Hills, MI)

Wilmington College (Wilmington, $\mathrm{OH}$ )

York College (York, NE) 
Table 2: Midwest, Comprehensive Colleges-Bachelor's submitting data to CAE

\begin{tabular}{|c|c|c|c|c|c|}
\hline Augustana College (Sioux Falls, SD) & 2002 & 2001 & 2000 & 1999 & 1998 \\
\hline Bethany College (Lindsborg, KS) & 2002 & 2001 & & & 1998 \\
\hline Bethel College (North Newton, KS) & 2002 & 2001 & 2000 & 1999 & 1998 \\
\hline Buena Vista University (Storm Lake, IA) & 2002 & 2001 & 2000 & 1999 & 1998 \\
\hline Calvin College (Grand Rapids, MI) & 2002 & 2001 & 2000 & 1999 & 1998 \\
\hline Carroll College (Waukesha, WI) & 2002 & 2001 & 2000 & 1999 & 1998 \\
\hline Cedarville University (Cedarville, $\mathrm{OH}$ ) & & & 2000 & 1999 & 1998 \\
\hline Central Christian College (McPherson, KS) & & & & & 1998 \\
\hline Central College (Pella, IA) & 2002 & 2001 & 2000 & 1999 & 1998 \\
\hline Central Methodist College (Fayette, MO) & 2002 & 2001 & 2000 & 1999 & 1998 \\
\hline Clarke College (Dubuque, IA) & 2002 & 2001 & 2000 & 1999 & 1998 \\
\hline College of the Ozarks (Point Lookout, MO) & 2002 & 2001 & 2000 & 1999 & \\
\hline Concordia University - St. Paul (St. Paul, MN) & 2002 & 2001 & & & 1998 \\
\hline Culver-Stockton College (Canton, MO) & 2002 & 2001 & 2000 & 1999 & 1998 \\
\hline Dana College (Blair, NE) & 2002 & 2001 & 2000 & 1999 & 1998 \\
\hline Defiance College (Defiance, OH) & 2002 & 2001 & 2000 & 1999 & 1998 \\
\hline Dordt College (Sioux Center, IA) & 2002 & 2001 & 2000 & 1999 & 1998 \\
\hline Elmhurst College (Elmhurst, IL) & 2002 & 2001 & 2000 & 1999 & 1998 \\
\hline Eureka College (Eureka, IL) & 2002 & 2001 & 2000 & & \\
\hline Franklin College (Franklin, IN) & 2002 & 2001 & 2000 & 1999 & 1998 \\
\hline Graceland University (Lamoni, IA) & 2002 & & & 1999 & 1998 \\
\hline Greenville College (Greenville, IL) & & & 2000 & 1999 & 1998 \\
\hline Huntington College (Huntington, IN) & 2002 & 2001 & & 1999 & 1998 \\
\hline Illinois College (Jacksonville, IL) & 2002 & 2001 & 2000 & 1999 & 1998 \\
\hline Iowa Wesleyan College (Mt. Pleasant, IA) & 2002 & 2001 & & & 1998 \\
\hline Judson College (Elgin, IL) & 2002 & 2001 & & & \\
\hline Loras College (Dubuque, IA) & 2002 & 2001 & 2000 & 1999 & 1998 \\
\hline Lourdes College (Sylvania, OH) & & & & & 1998 \\
\hline MacMurray College (Jacksonville, IL) & 2002 & 2001 & 2000 & 1999 & 1998 \\
\hline Manchester College (North Manchester, IN) & 2002 & 2001 & & 1999 & 1998 \\
\hline Marian College (Indianapolis, IN) & & & & 1999 & 1998 \\
\hline Marietta College (Marietta, $\mathrm{OH})$ & 2002 & 2001 & 2000 & 1999 & 1998 \\
\hline McKendree College (Lebanon, IL) & 2002 & 2001 & 2000 & 1999 & 1998 \\
\hline McPherson College (McPherson, KS) & 2002 & 2001 & 2000 & & 1998 \\
\hline Midland Lutheran College (Fremont, NE) & 2002 & 2001 & 2000 & 1999 & 1998 \\
\hline Millikin University (Decatur, IL) & 2002 & 2001 & 2000 & 1999 & 1998 \\
\hline Morningside College (Sioux City, IA) & 2002 & 2001 & 2000 & 1999 & 1998 \\
\hline Mount Mercy College (Cedar Rapids, IA) & 2002 & 2001 & 2000 & 1999 & 1998 \\
\hline Mount Union College (Alliance, $\mathrm{OH}$ ) & 2002 & 2001 & 2000 & 1999 & 1998 \\
\hline Mount Vernon Nazarene College (Mount Vernon, OH) & 2002 & 2001 & 2000 & 1999 & 1998 \\
\hline Northland College (Ashland, WI) & 2002 & 2001 & 2000 & 1999 & \\
\hline Northwestern College (Orange City, IA) & 2002 & 2001 & 2000 & 1999 & 1998 \\
\hline Northwestern College (St. Paul, MN) & & & & 1999 & 1998 \\
\hline Ohio Dominican University (Columbus, $\mathrm{OH}$ ) & 2002 & 2001 & 2000 & 1999 & 1998 \\
\hline Ohio Northern University (Ada, $\mathrm{OH})$ & 2002 & 2001 & 2000 & 1999 & 1998 \\
\hline Ottawa University (Ottawa, KS) & 2002 & 2001 & 2000 & 1999 & 1998 \\
\hline Otterbein College (Westerville, $\mathrm{OH}$ ) & 2002 & 2001 & 2000 & 1999 & 1998 \\
\hline Saint Mary's College (Orchard Lake, MI) & 2002 & 2001 & & & \\
\hline Simpson College (Indianola, IA) & 2002 & 2001 & 2000 & 1999 & 1998 \\
\hline Southwest State University (Marshall, MN) & 2002 & 2001 & 2000 & 1999 & 1998 \\
\hline Southwestern College (Winfield, KS) & 2002 & 2001 & 2000 & 1999 & \\
\hline Sterling College (Sterling, KS) & 2002 & 2001 & 2000 & 1999 & 1998 \\
\hline Taylor University (Upland, IN) & 2002 & 2001 & 2000 & 1999 & 1998 \\
\hline Tri-State University (Angola, IN) & 2002 & & & & \\
\hline Union College (Lincoln, NE) & 2002 & 2001 & 2000 & 1999 & 1998 \\
\hline
\end{tabular}


Waldorf College (Forest City, IA)

Wartburg College (Waverly, IA)

William Penn University (Oskaloosa, IA)

Wilmington College (Wilmington, $\mathrm{OH}$ )

$\begin{array}{llll}2002 & 2001 & 2000 & \\ 2002 & 2001 & 2000 & 199 \\ & & 2000 & 199 \\ 2002 & 2001 & 2000 & 199\end{array}$

1998

1999

$1999 \quad 1998$

Italics indicates that year's survey was disqualified due to missing study-specific data

prospective link that might drive those variables identified in the first wave. This process continued until several hypothesized models emerged with at least one variable present from advancement's three core activities.

For each hypothesized model, model estimation was achieved by a computer program designed to build SEMs. The AMOS 4 program was used. ${ }^{26}$ The covariance matrix was analyzed using maximum likelihood method. Each estimated model was then assessed for fitness and the final model prepared for presentation. The results of these procedures follow.

\section{Results}

Model specification and estimation Several hypothesized structural equation models were specified and then estimated to examine the direct and indirect

Table 3: FY00-02 top quartile

\begin{tabular}{|c|c|c|c|}
\hline Augustana College (Sioux Falls, SD) & 1998 & McPherson College (McPherson, KS) & 2001 \\
\hline Augustana College (Sioux Falls, SD) & 2001 & Millikin University (Decatur, IL) & 1998 \\
\hline Bethel College (North Newton, KS) & 1998 & Millikin University (Decatur, IL) & 1999 \\
\hline Calvin College (Grand Rapids, MI) & 1998 & Millikin University (Decatur, IL) & 2001 \\
\hline Calvin College (Grand Rapids, MI) & 1999 & Millikin University (Decatur, IL) & 2002 \\
\hline Calvin College (Grand Rapids, MI) & 2000 & Mount Union College (Alliance, $\mathrm{OH}$ ) & 1998 \\
\hline Calvin College (Grand Rapids, MI) & 2001 & Mount Union College (Alliance, $\mathrm{OH}$ ) & 2000 \\
\hline Calvin College (Grand Rapids, MI) & 2002 & Mount Union College (Alliance, $\mathrm{OH}$ ) & 2001 \\
\hline Cedarville University (Cedarville, $\mathrm{OH}$ ) & 1999 & Mount Union College (Alliance, $\mathrm{OH}$ ) & 2002 \\
\hline Cedarville University (Cedarville, $\mathrm{OH}$ ) & 2000 & Northland College (Ashland, WI) & 1999 \\
\hline Central College (Pella, IA) & 2001 & Northland College (Ashland, WI) & 2001 \\
\hline College of the Ozarks (Point Lookout, MO) & 1999 & Northland College (Ashland, WI) & 2002 \\
\hline College of the Ozarks (Point Lookout, MO) & 2000 & Northwestern College (Orange City, IA) & 2001 \\
\hline College of the Ozarks (Point Lookout, MO) & 2001 & Ohio Northern University (Ada, $\mathrm{OH}$ ) & 1999 \\
\hline College of the Ozarks (Point Lookout, MO) & 2002 & Ohio Northern University (Ada, OH) & 2000 \\
\hline Franklin College (Franklin, IN) & 2001 & Ohio Northern University (Ada, OH) & 2001 \\
\hline Huntington College (Huntington, IN) & 2001 & Otterbein College (Westerville, $\mathrm{OH}$ ) & 1998 \\
\hline Illinois College (Jacksonville, IL) & 1998 & Otterbein College (Westerville, $\mathrm{OH}$ ) & 2000 \\
\hline Illinois College (Jacksonville, IL) & 1999 & Otterbein College (Westerville, OH) & 2001 \\
\hline Illinois College (Jacksonville, IL) & 2000 & Otterbein College (Westerville, OH) & 2002 \\
\hline Loras College (Dubuque, IA) & 2000 & Saint Mary’s College (Orchard Lake, MI) & 2001 \\
\hline Loras College (Dubuque, IA) & 2001 & Simpson College (Indianola, IA) & 2000 \\
\hline Manchester College (North Manchester, IN) & 2001 & Taylor University (Upland, IN) & 1998 \\
\hline Manchester College (North Manchester, IN) & 2002 & Taylor University (Upland, IN) & 1999 \\
\hline Marietta College (Marietta, OH) & 1999 & Taylor University (Upland, IN) & 2000 \\
\hline Marietta College (Marietta, $\mathrm{OH})$ & 2001 & Taylor University (Upland, IN) & 2001 \\
\hline Marietta College (Marietta, OH) & 2002 & Taylor University (Upland, IN) & 2002 \\
\hline McKendree College (Lebanon, IL) & 2000 & Wartburg College (Waverly, IA) & 1999 \\
\hline McPherson College (McPherson, KS) & 1998 & Wartburg College (Waverly, IA) & 2000 \\
\hline
\end{tabular}




\section{Table 4: Variables defined}

\section{Development}

Total voluntary support-sum of all outright and deferred gifts

Voluntary support by the governing board-current, former, and emeriti members of the Board of Trustees

Voluntary support by constituent:

- Alumni-former students (full- or part-time, undergraduate or graduate) who have earned some credit toward a degree

- Parents-persons, other than alumni, who are the parents of either currently enrolled or former students

- Other individuals-all persons who are not classified under the above definitions

- Corporations-corporations, partnerships, and cooperatives that have been organized for profit-making purposes

- Foundations-private tax-exempt entities, whether corporate or trust in legal form-operated for charitable purposes

- Religious organizations-churches, synagogues, and temples, and their denominational entities

- Fund-raising consortia-entities that have been formed by a group of cooperating institutions for the purpose of facilitating their fund raising activities

- Other organizations-all organizations, other than government agencies, not defined above

Voluntary support by designation:

- Unrestricted giving for current operations-gifts, in any form, including bequests, given by donors without restriction

- Restricted giving for current operations-gifts for current operations on which the donor placed a restriction

- Total current operations giving-the sum of the above

- Giving for property, buildings, and equipment-gifts of both real and personal property, as well as gifts for

- Unrestricted giving for endowment-gifts restricted by donors for endowment, but not bearing any restriction as to the use of the income the endowment produces

- Restricted giving for endowment-gifts restricted by donors for endowment, from which the income is limited by the donor for specific purposes or programs

- Loan funds-gifts restricted by donors to be used to make loans to students, faculty, and staff

- Total capital and endowment giving-sum of the above

- Total deferred giving (at face value)-full face amount of deferred gifts

Voluntary support matrix by constituent $\mathrm{x}$ by designation

(72 cells of analysis intersecting the above largest gifts)

- Sum of the three largest corporate gifts

- Sum of the three largest foundation gifts

- Sum of the three largest living individual gifts

- Sum of the three largest bequest gifts

- Sum of the 12 largest gifts from corporations, foundations, living individuals, and bequests

\section{Alumni Relations}

Percentage of alumni (of record) who contributed

Total number of alumni donors giving to current operations

Alumni of record-those living alumni for whom there are current addresses

\section{Public Relations}

Academic reputation (from US Neres \& World Report)-survey assessment by administrators (presidents, provosts, and deans of admission) at peer institutions

(All data from the Council for Aid to Education, unless otherwise specified)

relationships of variables on total voluntary support. The "best fitting" model, without the measurement errors and disturbances, is shown in Figure 5.
The model comprises seven observed variables, and the figure also includes the standardized coefficients and the squared multiple correlations within the model. 


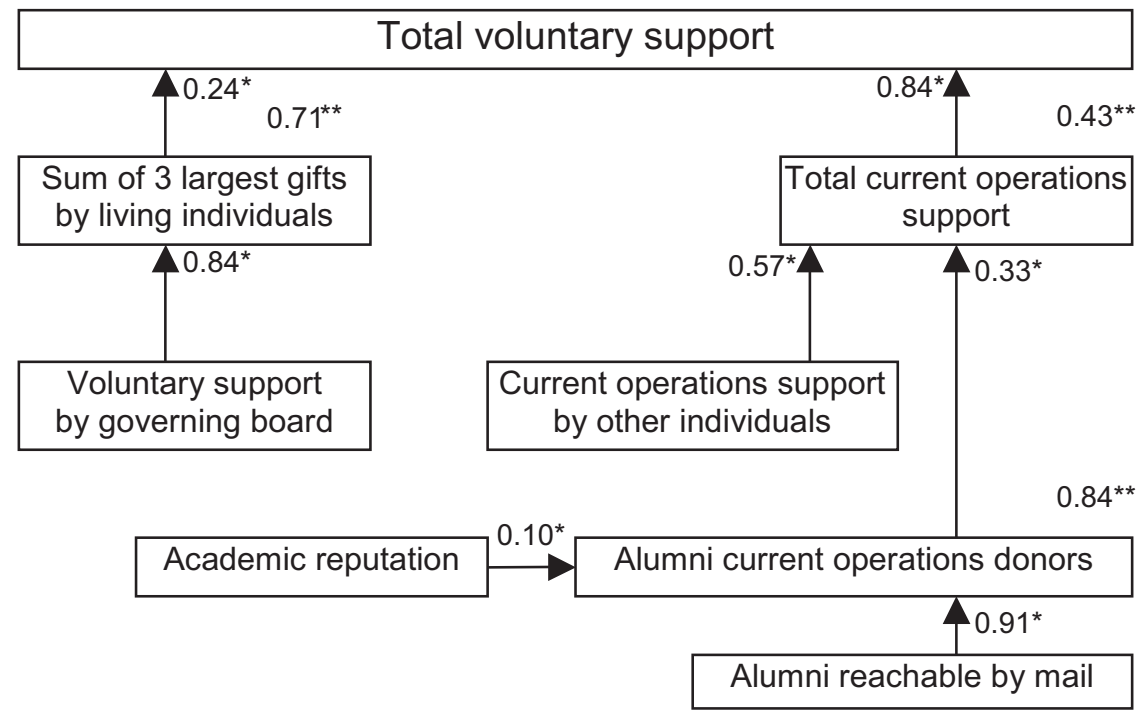

Figure 5: The structural equation model with standardized coefficients and $R^{2}$

"Indicates standardized coefficient; "*Indicates squared multiple correlations

The data were then analyzed with AMOS 4. The results are presented in Tables 5 and 6 . To summarize the results:

1. Two variables were found to have a direct effect on total voluntary support:

(a) sum of the three largest gifts by living individuals, and

(b) voluntary support designated for current operations.

2. The sum of the three largest gifts by living individuals had one variable affecting it: voluntary support by the governing board.

3. Voluntary support designated for current operations had two variables affecting it:

(a) total current operations support by other individuals, and

(b) alumni donors designating to current operations.

4. Alumni donors designating to current operations had two variables affecting it: (a) alumni who are reachable by mail, and

(b) academic reputation.

\section{Model fit}

Numerous indices exist for assessing how well a model fits its data, ${ }^{27}$ and the ones given in Table 5 represent several absolute, incremental, and parsimonious goodnessof-fit measures. The absolute measure (p) reveals that the statistical significance is better than 0.001 , which represents an acceptable fit. The incremental measures, comparing the estimated model to a null model, are all greater than 0.90 , which represents an acceptable fit. Finally, the parsimonious measure, adjusting for the number of parameters in the estimated model, is acceptable by some standards, ${ }^{28}$ and close by others, ${ }^{29}$ as the normed- $\chi^{2}$ is 2.391 .

Overall, the exploratory model appears to have goodness-of-fit. 
Table 5: Fit measures

\begin{tabular}{lllc}
\hline Measures & Default model & Saturated model & Null model \\
\hline $\begin{array}{l}\text { Absolute fit } \\
\chi^{2}\end{array}$ & 50.209 & & \\
Degrees of freedom (df) & 20 & 0.000 & 360.996 \\
$\mathrm{p}$ & $<0.001$ & & \\
Incremental fit & 0.948 & 1.000 & 0.000 \\
Normed fit index & 0.910 & 1.000 & 0.000 \\
Relative fit index & 0.969 & & 0.000 \\
Incremental fit index & 0.946 & 1.000 & 0.000 \\
Tucker-Lewis index & 0.968 & 26.694 & 0.000 \\
Comparative fit index & 2.391 & & \\
Parsimonious fit & & & \\
$\chi^{2} /$ df & & & \\
\hline
\end{tabular}

\section{Model presentation}

Based on the critical ratios generated from AMOS 4 (Table 6), all structural paths are significant. Furthermore, six of the seven causal links are significant at better than 0.001, while the link between academic reputation and alumni donors designating to current operations is significant at 0.05 . In summary, the exploratory model appears to have both goodness-of-fit and structural integrity.

\section{Discussion}

To review, the goal of building a structural equation model is "to find a model that fits the data well enough to serve as a useful representation of reality and a parsimonious explanation of the data." 30 This exploratory model appears to achieve that goal. Most of all, the three core activities that comprise the advancement enterprise are each represented in the final model by seven

Table 6: Regression weights

\begin{tabular}{|c|c|c|c|c|}
\hline Estimate & Standard error & & Critical ratio & $\mathrm{p}$ \\
\hline \multicolumn{2}{|c|}{ Alumni current operations donors } & \multirow[t]{2}{*}{$\leftarrow$} & \multicolumn{2}{|c|}{ Alumni of record } \\
\hline 0.223 & 0.013 & & 17.341 & $<0.001$ \\
\hline \multicolumn{2}{|c|}{ Alumni current operations donors } & \multirow[t]{2}{*}{$\leftarrow$} & \multicolumn{2}{|c|}{ Academic reputation } \\
\hline 787.019 & 396.553 & & 1.985 & $<0.05$ \\
\hline \multicolumn{2}{|c|}{ Total current operations support } & \multirow[t]{2}{*}{$\leftarrow$} & \multicolumn{2}{|c|}{ Alumni current operations donors } \\
\hline 496.887 & 151.516 & & 3.279 & $<0.001$ \\
\hline \multicolumn{2}{|c|}{ Sum 3 Largest gifts by living individuals } & \multirow[t]{2}{*}{$\leftarrow$} & \multicolumn{2}{|c|}{ Voluntary support by governing board } \\
\hline 0.793 & 0.067 & & 11.850 & $<0.001$ \\
\hline \multicolumn{2}{|c|}{ Total current operations support } & \multirow[t]{2}{*}{$\leftarrow$} & \multicolumn{2}{|c|}{ Current operations support by other individuals } \\
\hline 1.057 & 0.185 & & 5.722 & $<0.001$ \\
\hline \multicolumn{2}{|c|}{ Total voluntary support } & \multirow[t]{2}{*}{$\leftarrow$} & \multicolumn{2}{|c|}{ Total current operations support } \\
\hline 0.951 & 0.074 & & 12.917 & $<0.001$ \\
\hline \multicolumn{2}{|c|}{ Total voluntary support } & \multirow[t]{2}{*}{$\leftarrow$} & \multicolumn{2}{|c|}{ Sum 3 Largest gifts by living individuals } \\
\hline 0.620 & 0.167 & & 3.721 & $<0.001$ \\
\hline
\end{tabular}


variables. Each variable also represents a measure, or outcome, of a core advancement activity. In other words, academic reputation is a measure of public relations, alumni reachable by mail and alumni current operations donors are measures of alumni relations, and the four remaining variables are measures of development.

In addition, as development, at a minimum, includes the key functions of annual giving, major giving, deferred giving, and corporate and foundation grants, those variables assigned to development as outcome measures can be further assigned to one of the key functions of development. That is, current operations support by other individuals and total current operations support are measures of annual giving; and voluntary support by governing board and sum of the three largest gifts by living individuals are measures of major giving. Figure 6 then emerges as a restatement, or refinement, of the "best fitting" structural equation model into the exploratory advancement value chain. As such, the causal links that fall within advancement's core activities (public relations, alumni relations, and development), and drive total giving for the institution, are also identified in Figure 6.

Total giving represents the ultimate measure of success for the expectations of the advancement enterprise. Even though the goals of alumni relations and public relations are building friends and strengthening image, at the end of the year, the total funds raised have the single greatest impact on advancement's

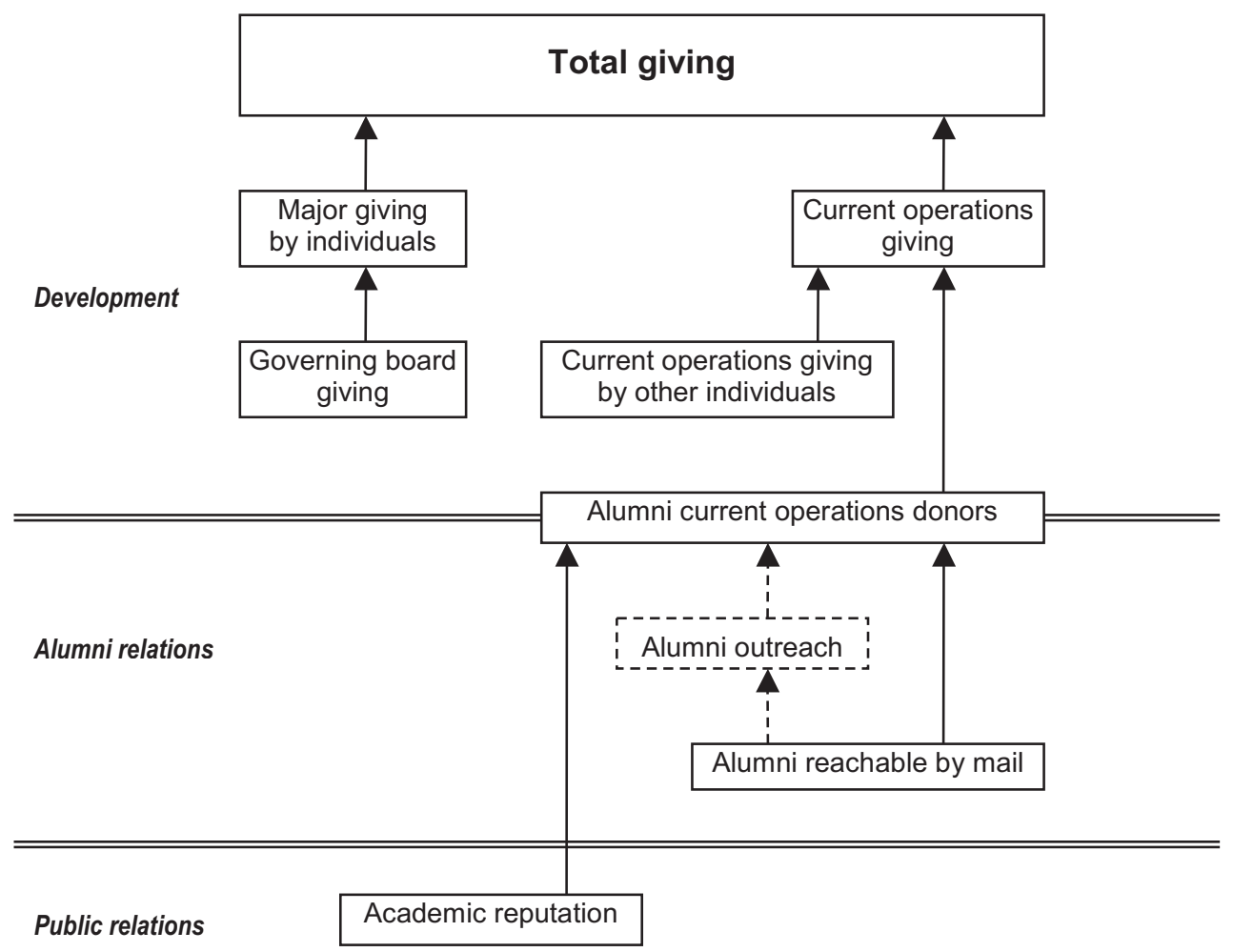

Figure 6: The advancement value chain 
celebration. Accordingly, each link in the value chain strengthens and holds together the institution's efforts to generate greater levels of voluntary financial support.

\section{Development}

Major giving by individuals and current operations giving drives total giving. As a measure of major giving, the sum of the three largest gifts by individuals emphasizes the importance of the institution's commitment to significant levels of major giving, either outright or deferred. "Though the dollar amount of a major gift may vary from institution to institution, all major gifts share a common characteristic: major gifts have a significant impact on the giving area or purpose to which they are directed." 31 Outright major gifts are gifts from a donor's assets-for example, appreciated stocks. As outright major giving tracks closely to the performance of the New York Stock Exchange Composite Index, ${ }^{32}$ the decade of the 1990s saw outright major gifts become outright mega-gifts. Over the last three years, however, as the stock market has struggled, deferred major gifts have become "critically important at a time when many donors are inclined to put off their philanthropy." 33

On the other hand, current operations giving is a measure of development's annual giving program. Annual giving is tasked to secure gifts for current operations and, while the perception may be held that annual giving is the "entry point" to the development cycle, annual giving is as important a link in the advancement value chain as major giving is.

Two observations may be made from this link relative to advancement priority setting. First, this link dispels the myth that annual giving is subordinate to major giving. The advancement value chain demonstrates that an annual giving program constructed to increase the institution's current operations support is a full partner with development programs responsible for major giving. The second observation is that the primary focus of major giving must be on individuals. This link does not imply that major gifts from corporations and foundations are not vital to the institution, because they are. This link of the advancement value chain instead implies that a driver to total giving to the institution is major gifts from individuals. In addition, this link supports the established fact that approximately two-thirds of giving each year to private liberal arts institutions comes from individual donors, ${ }^{34}$ as opposed to corporate and foundation donors.

Governing board giving drives major giving by individuals. This link underscores the fact that 'the trustees' willingness to give sets the margin of difference for an institution. No small college can advance beyond the trustees' capacity to give." 35 Regardless of whether governing board giving drives major giving by individuals due to board members being major donors themselves, or actively soliciting major gifts, or both, this link makes clear that the governing board must "give" first and "give" more to lead the way for "getting." "Good board members must have faith in their institutions, and personal giving is a strong demonstration of this attachment." "But the role of the board members extends beyond this. They must encourage-indeed ask-their friends, colleagues, associates, and peers to become major donors as well." ${ }^{37}$ As a result, board identification, recruitment, and development must therefore be grounded more on "wealth"-the ability to give and the ability to get-than on 
"wisdom" or "work," the three "w's" on which all boards and their memberships are built.

Moreover, because of the significant symbiotic relationship between president and governing board, ${ }^{38}$ this link creates a challenging rock-scissors-paper circular paradox for the institution. That is, the governing board hires the president, who is charged with securing more financial resources-"rock breaks scissors." Then the president hires a chief advancement officer, who is delegated the responsibility to generate ever-increasing levels of voluntary financial support-"scissors cut paper." Lastly, the chief advancement officer-in partnership with the presidentcounsels the governing board that they must philanthropically and sacrificially lead by example-" "paper covers rock." This link makes clear that, for job security and goal accomplishment, both the chief advancement officer and president must have active roles in board member identification, recruitment, and development, and, in addition, philanthropic expectations for board members must be communicated throughout the board building process.

The importance of this link-both as part of the advancement value chain and to the institution's president-was strengthened by Nelson when he observed, "Presidents need their boards to be successful (especially in the area of fund raising) if they are to have any chance of succeeding themselves." 39

Current operations giving by other individuals and alumni current operations donors drive current operations giving. Current operations giving by other individuals reinforces the value of reaching beyond the institution's traditional individual constituentsreaching beyond alumni and parents-and finding prospective "friends of the college" who will share the institution's mission and, even more importantly, invest in it. The other driver of current operations giving is the number of alumni donors giving to current operations. This is an absolute measure, in contrast to the percentage of the alumni (of record) who give. While US Neres \& World Report, and those institutions chasing top rankings as the pursuit of the Holy Grail, place value on the percentage of alumni who give, the advancement value chain, on the other hand, places value on the number of alumni who give. Within the advancement value chain, quantity of alumni giving to the institution has greater value than the quality of alumni, measured in terms of the percentage who give.
Alumni and public relations Academic reputation and alumni reachable by mail drive alumni current operations donors. Academic reputation represents a perceived quality of the institution's diploma as assessed by the presidents, provosts, and deans of admissions at peer institutions. As that reputed quality increases, alumni have the most to gain from their institution's heightened status. The advancement value chain, therefore, demonstrates that alumni appear to respond with gifts directed toward the institution's budget (current operations). Institutions often market these current operations gifts as the economic value- added margin to academic excellence for the institution, thereby helping to enhance the perceived quality and status of the institution. This creates an upward spiral that benefits both alumni and institution, and supports a finding by Baade and Sundberg that quality rankings are important motivators to alumni contributions. ${ }^{40}$
Furthermore, potentially hidden beneath academic reputation driving 
alumni current operations donors is a model within the model (Figure 7). Academic reputation (or quality rankings) and its link to alumni current operations donors appears to possibly support the concept of psychological identification, ${ }^{41}$ which is defined as "a collection of people who share the same social identification or define themselves in terms of the same social category membership." 42 In other words, alumni have a psychological identification that bonds them with their institution; the institution is assigned some quality ranking that represents the institution's academic status; academic status is internalized by alumni which subsequently affects their self-esteem; alumni self-esteem thereby drives alumni to contribute (or not to contribute). Or, simply within the confines of this exploratory advancement value chain, academic reputation drives alumni donors.

Alumni reachable by mail emphasizes that the number of alumni the institution can potentially contact-in this measure, by mail-has an effect on the dollars raised. Working as the other driver of alumni current operations donors, those institutions with larger alumni databases have a definite advantage in potentially securing greater levels of financial support. The implication of this link for the advancement enterprise is clear. There must be a commitment to locating lost alumni and sustaining database accuracy. Furthermore, while CAE only collects data regarding alumni reachable by mail, alumni reachable by telephone is not collected, and as the twenty-first century unfolds, the future most likely lies in alumni reachable by email. Extrapolating from that premise, this link also makes the case for accuracy and utilization of telephone numbers and email addresses as well.

Even more importantly, however, is that alumni reachable by mail serves as the foundation for alumni marketing intelligence. Like the academic reputation link, this link might also have beneath it a possible hidden model within the model (Figure 8). That is, demographic factorsage, sex, martial status, location of residence, degrees earned, occupation, income, and beliefs-have been shown to influence alumni giving. ${ }^{43}$ These factors cannot be utilized by the institution to segment the alumni marketplace for greater solicitation effectiveness, if the institution does not first have the ability to reach alumni by mail. Therefore, while the advancement value chain shows that alumni reachable by mail drives alumni current operations donors, what might be hidden beneath this particular link in the advancement value chain is that one or more demographic causes

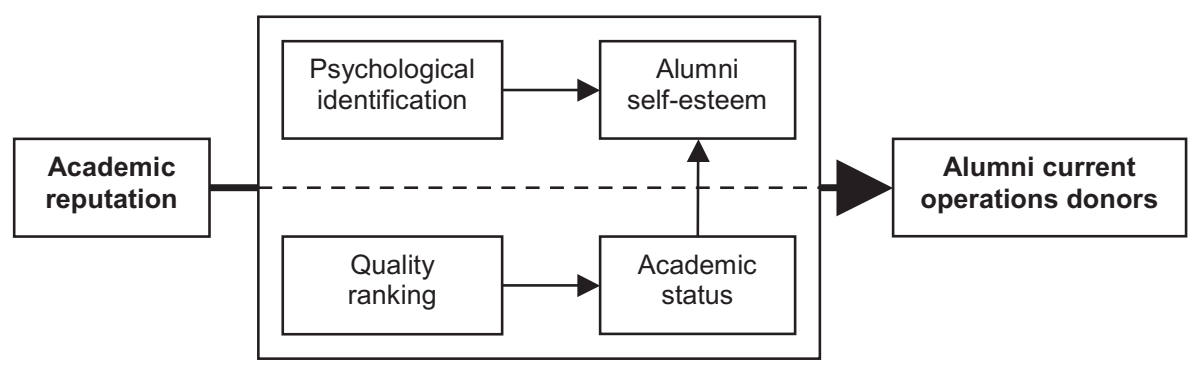

Figure 7: Academic reputation hidden value chain 


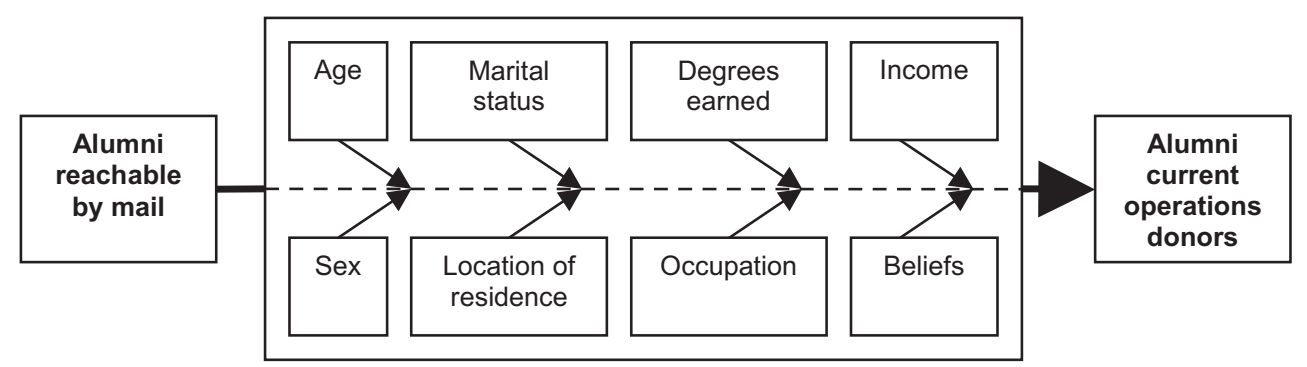

Figure 8: Alumni rerach hidden value chain

might be in play to also drive alumni to give.

Alumni outreach may drive alumni current operations donors and alumni reachable by mail may drive alumni outreach. Alumni outreach, as a link in the advancement value chain, represents a theoretical extension of the structural equation model. Because neither CASE nor CAE collects any data of alumni participation or involvement, empirically analyzing this variable within the structural equation model is impossible. However, researchers have shown that a correlation exists between alumni who actively participate and alumni who give. "Simply put, the stronger the relationship, the more likely they are to be donors." 45

In addition, a second theoretical extension would be that alumni reachable by mail drives alumni outreach. The rationale and its role as a link in the advancement value chain parallels the previous discussion on alumni reachable by mail driving alumni current operations donors. That is, for the same reasons that alumni reach empirically drives alumni donors, alumni reach theoretically drives alumni participation and involvement.

\section{Conclusion}

This exploratory advancement value chain study empirically affirms many theoretically held beliefs regarding the path to expanded philanthropy for the institution. This study also confirms and validates the important common work of public relations, alumni relations, and development in generating ever-increasing levels of voluntary financial support for the institution. It also strengthens the chief advancement officer's ongoing encouragement of teamwork among the three core activities for philanthropic success to be realized.

Further studies should seek to expand and refine the links that form the advancement value chain. All possible links must be considered and as the links that form the advancement value chain are forged with more and better data, the overall strength of the value chain-and its role as both a strategic and tactical planning tool-will be galvanized. For example, there is a need for more and better alumni relations data within the public domain (possibly to be collected by CAE or CASE), such as: alumni reachable by telephone and by email, alumni attendance at Homecoming and/or Alumni Weekend (or similar large campus alumni event), and the number of alumni who serve as volunteers for the institution (i.e., admissions, class agents, reunion committees, etc.). Further studies should also seek to tie more closely the advancement enterprise value chain with the business enterprise value chain and, as 
such, would need access to employee data. Employee measures are critical links in the business enterprise value chains, and in directly and indirectly driving financial performance. However, there is a need for employee information within the public domain.

In conclusion, and most importantly, as an exploratory model, the advancement value chain puts one more tool into the president's and chief advancement officer's toolbox to secure higher levels of philanthropy for the institution. To paraphrase Heskett et al., ${ }^{46}$ relating all the links in the advancement value chain may seem a tall task, but expanding philanthropy depends on linking those individual measures into a comprehensive and integrated advancement value chain. Small, private colleges and universities must increase voluntary financial support to survive and thrive and need to quantify their return on investment in advancement and its core activities-public relations, alumni relations, and development. The advancement value chain provides that framework for this critical task, so that, as Maister concluded, "for the first time, we can now actually look at the [philanthropic] implication of various managerial and policy decisions in a rigorous way."

\section{References}

1. M. E. Porter (1985), Competitive Advantage: Creating and Sustaining Superior Performance, The Free Press, New York, p. 36.

2. J. L. Heskett, W. E. Sasser, and L. A. Schlesinger (1994), The Service Profit Chain: How Leading Companies Link Profit and Growth to Loyalty, Satisfaction, and Value, The Free Press, New York; J. L. Heskett, W. E. Sasser, and L. A. Schlesinger (2002), The Value Profit Chain: Treat Employees Like Customers and Customers Like Employees, The Free Press, New York.

3. Heskett, Sasser, and Schlesinger (1994), The Service Profit Chain, op. cit., p. 18.

4. A. J. Rucci, S. P. Kirn, and R. T. Quinn (1998), "The employee-customer-profit chain at Sears,"
Harvard Business Review, 76, 1, 83-97, quotation p. 83.

5. D. H. Maister (2001), Practice What You Preach: What Mangers Must do to Create a High-Achievement Culture, The Free Press, New York, p. 84.

6. C. Coffman and G. Gonzalez-Molina (2002), Follow This Path: How the World's Greatest Organizations Drive Growth by Unleashing Human Potential, Warner Books, New York.

7. W. K. Willmer (2001), "Study overview," in W. K. Willmer (Ed.), Advancing Small Colleges: Strategies for Success in Alumni Relations, Communications, Fund Raising, Marketing, and Enrollment Management," Council for the Advancement and Support of Education, Washington, DC, p. 1.

8. W. K. Willmer (2001), "Leading and managing the process," in Willmer (Ed.), Advancing Small Colleges, op. cit., pp. 11-30, quotation p. 12.

9. G. I. Douglas (2001), "Integrated marketing: an evolving paradigm for college communications," in Willmer (ed.), Advancing Small Colleges, op. cit., p. 120.

10. R. E. Bee (2001), "The successful small alumni relations office," in Willmer (Ed.), Advancing Small Colleges, op. cit., p. 161.

11. Ibid., p. 158.

12. D. L. Miller (2001), "Raising funds for small colleges and universities," in Willmer (Ed.), Advancing Small Colleges, op. cit., p. 93.

13. National Society of Fund Raising Executives Institute (1986), Glossary of Fund-raising Terms, National Society of Fund Raising Executives Institute, Alexandria, VA, p. 63.

14. Ibid., p. 28.

15. Ibid., p. 46.

16. Ibid., p. 4

17. A. E. Kaplan (2002), 2002 Voluntary Support of Education, Council for Aid to Education, New York.

18. J. E. Hair, Jr., R. E. Anderson, R. L. Tatham and W. C. Black (1998), Multivariate Data Analysis, 5th edn., Prentice Hall, Upper Saddle River, NJ, p. 586.

19. R. E. Schumacker and R. G. Lomax (1996), $A$ Beginner's Guide to Structural Equation Modeling, Lawrence Erlbaum Associates, Mahwah, NJ.

20. R. Stoelting (2002), "Structural equation modeling/ path analysis," <http://online.sfsu.edu/ efc/classes/ biol710/path/SEMwebpage.htm>.

21. J. B. Ullman (1996), "Structural equation modeling," in B. G. Tabachnick and L. S. Fidell (Eds.), Using Multivariate Statistics, 3rd edn., Harper Collins, New York, pp. 708-819; R. H. Hoyle (1995), Structural Equation Modeling, Sage Publications, Thousand Oaks, CA.

22. Hair et al. (1998), Multivariate Data Analysis, op. cit.; Ullman (1996), "Structural equation modeling," op. cit.

23. Ullman (1996), "Structural equation modeling," op. cit. 
24. E. G. Carmines and J. P. McIver (1981), “Analyzing models with unobserved variables: analysis of covariance structures," in G. W. Bohmstedt and E. F. Borgatta (Eds.), Social Measurement, Sage Publications, Thousand Oaks, CA, pp. 65-115; R. B. Kline (1998), Principles and Practice of Structure Equation Modeling, Guilford Press, New York.

25. Ullman (1996), "Structural equation modeling," op. cit.

26. J. L. Arbuckle (1999), AMOS User's Guide: Version 4, SPSS, Chicago.

27. Schumacker and Lomax, (1996), A Beginner's Guide to Structural Equation Modeling, op. cit.; Ullman (1996), "Structural equation modeling," op. cit.

28. Carmines and McIver (1981), "Analyzing models with unobserved variables,” op. cit.; Kline (1998), Principles and Practice of Structure Equation Modeling, op. cit.

29. Ullman (1996), "Structural equation modeling," op. cit.

30. Stoelting (2002), "Structural equation modeling/ path analysis," op. cit.

31. J. Cosovich (1993), "An introduction to the major giving process," in R. Muir and J. May (Eds.), Developing an Effective Major Gifts Program: From Managing Staff to Soliciting Gifts, Council for the Advancement and Support of Education, Washington, DC, p. 2.

32. B. McClintock (2002), Philanthropic Trends at Educational Institutions: Fiscal Years 1992-2001, Marts and Lundy, Lyndhurst, NJ.

33. J. L. Pulley (2003). "Struggling against the tide," Chronicle of Higher Education, February 28, pp. A2931, quotation p. A30.

34. Kaplan (2002), 2002 Voluntary Support of Education, op. cit.

35. R. W. Neff (1993), "The trustees' critical role in small college advancement," in W. K. Willmer (Ed.), Winning Strategies in Challenging Times for Advancing Small Colleges, Council for the Advancement and Support of Education, Washington, DC, p. 97.

36. J. W. Pocock (1989), "Trustee giving-and other tasks," in Pocock (Ed.), Fund-raising Leadership: A Guide for College and University Boards, Association of Governing Boards of Universities and Colleges, Washington, DC, p. 41.

37. K. Dove (1989), "Why major donors give," in Pocock (Ed.), Fund-raising Leadership: A Guide for College and University Boards," op. cit., p. 77.
38. S. J. Nelson (2003). "Internal journeys of college presidents: diary reflections about leadership and values: Part IV," Journal of College and Character, <http://www.collegevalues.org/ articles.cfm? $\mathrm{a}=1 \& \mathrm{id}=979>$.

39. Ibid.

40. R. Baade and J. Sundberg (1993), "Identifying the factors that stimulate alumni giving," Chronicle of Higher Education, September 29, pp. B1-2.

41. F. A. Mael (2001), "Organizational identification and its relevance to college alumni," paper given at Association of Institutional Research/Council for the Advancement and Support of Education," 4th Annual Research Colloquium, Columbus, $\mathrm{OH}$, April.

42. J. C. Turner (1984), "Social identification and psychological group formation," in H. Tajfel (Ed.), The Social Dimension: European Developments in Social Psychology, vol. 2, Cambridge University Press, Cambridge, UK, pp. 518-38, quotation p. 530.

43. B. E. Brittingham and T. R. Pezzullo (1990), "The campus green: Fund raising in higher education," ASHE-ERIC Higher Education Report No. 1, School of Education and Human Development, The George Washington University, Washington, DC; J. W. Mosser (1993). "Predicting alumni/ae gift giving behavior: A structural equation model approach," ERIC Document Reproduction Service No. ED 355 883

44. Baade and Sundberg (1993), "Identifying the factors that stimulate alumni giving," op. cit.; Brittingham and Pezzullo (1990), "The campus green,” op. cit.; R. J. Parsons, L. C. Walters, H. B. Higley, A. L. Taylor, J. C. Martin, Jr., and A. Viswadoss (1995), "Studying alumni affinity," Advancing Philanthropy, 3, 2, pp. 57-9; P. S. Young and N. M. Fischer (1996), "Identifying undergraduate and post-college characteristics that may affect alumni giving," paper given at Association for Institutional Research 36th Annual Forum, Albuquerque, NM, May, ERIC Document Reproduction Service No. EJ 584110.

45. J. Pearson (1999), "Comprehensive research on alumni relationships: Four years of market research at Stanford University," New Directions for Institutional Research, 26, 1, 5-21, quotation p. 7.

46. Heskett et al. (1994), The Service Profit Chain, op. cit.

47. Maister (2001), Practice What You Preach, op. cit., p. 84

\section{Practitioner's Perspective}

Dr. Leonard quickly establishes the multivariable links between customer satisfaction and loyalty and employee productivity and satisfaction in the for-profit world. Employee satisfaction drives customer loyalty, which drives sales and, ultimately, profit. These "real world" value chains are concepts the not-for-profit world has been 
extremely slow to embrace. However, Leonard's evidence can be so simply converted to educational advancement because (1) we are consolidating our fund- and friendraising activities much more rapidly, and (2) budget realities are forcing us to organize strategically as a complement of talent rather than a set of independent programs.

Within the obvious equation of satisfaction, loyalty, productivity, and profit lies the basis for all we do in advancement. We are in the business of winning friends and influencing people to make strategic and thoughtful gifts to our institutions. After all of the statistical data gathering, formula development, and data mining, Leonard offers the practitioner (and those of us who are statistically challenged) a simple formula that we all can use to build our own advancement value chain model: "specify at least one variable from each of advancement's three core activities." For some of us, our structural equation model evolves from a four-core activity with government relations added to the mix.

Regardless of the number of core activities, we can build our value chain model by identifying the variables with the strongest positive correlations that are driving total voluntary support at our institutions. As Leonard demonstrates, advancement's collective responsibility is raising private voluntary support in a rational and interconnected way. The beauty of the advancement value chain is the simplicity with which it draws our human and financial resources together to achieve our singular philanthropic goal. At Louisville, the employee effort and productivity to donor satisfaction and institutional loyalty equation will be fully developed.

Vice President, University Advancement, University of Louisville, Louisville, Kentucky 